\title{
Isolation of Pythium Species from Zoysia Grass and Their Effect on Severity of Large Patch Disease
}

\author{
A. Aoyagi, K. Kageyama, and M. Hyakumachi, Laboratory of Plant Disease Science, Faculty of Agriculture, Gifu \\ University, 1-1 Yanagido, Gifu 501-11, Japan
}

\begin{abstract}
Aoyagi, A., Kageyama, K., and Hyakumachi, M. 1999. Isolation of Pythium species from zoysia grass and their effect on severity of large patch disease. Plant Dis. 83:171-175.

Pythium periplocum, P. rostratum, P. torulosum, and P. vanterpoolii were predominant Pythium species isolated from nine sites with a history of large patch disease of zoysia grass. Rhizoctonia solani AG2-2 LP and the Pythium species were isolated from 21 sod samples of zoysia grass exhibiting large patch symptoms in five golf courses. $R$. solani AG2-2 LP was obtained from all samples, while $P$. periplocum, $P$. rostratum, $P$. torulosum, and $P$. vanterpoolii were obtained from 14, 6, 11, and 8 samples, respectively. At least one of the four Pythium species was recovered from 19 samples. To verify pathogenicity of these four species of Pythium on zoysia grass, they were inoculated alone and together with $R$. solani AG2-2 LP on zoysia grass. When individual isolates were used to inoculate zoysia grass, $R$. solani AG2-2 LP, $P$. periplocum, and $P$. vanterpoolii were moderately aggressive, while $P$. torulosum and $P$. rostratum caused little or no disease. Symptoms produced by $R$. solani AG2-2 LP included orange discoloration of the sheath, and the sheath was easily pulled from the crown. P. periplocum and $P$. vanterpoolii induced only sheath chlorosis, and the sheath was not easily removed from the crown. In coinoculation tests, the combination of $R$. solani AG2-2 LP and P. torulosum intensified disease severity on zoysia grass and induced more rapid symptom development than did $R$. solani AG22 LP alone. The combination of $R$. solani AG2-2 LP and P. periplocum or P. vanterpoolii resulted in sheath necrosis and bare patches, similar to large patch symptoms observed on golf courses.
\end{abstract}

Large patch disease has been reported in Japan (4) and North America (8), and it occurs during spring and fall when air temperatures are approximately $20^{\circ} \mathrm{C}$. The disease occurs on some warm-season turfgrasses, including Bermuda grass (Cynodon dactylon), centipede grass (Eremochloa ophiuroides), St. Augustine's grass (Stenotaphrum secundatum), and zoysia grass (Zoysia spp.) (6). The disease usually develops in early May to mid-tolate June and disappears by July with the increase in air temperature. In fall, large patch disease usually develops in midSeptember as turf becomes dormant. During turf dormancy, the patches are not distinct and do not expand. Disease incidence also is increased by rainfall (6). The causal agent of large patch disease was originally described as Rhizoctonia solani AG2-2IV (30), but is now known to comprise a unique subgroup of $R$. solani designated AG2-2 LP $(16,17)$. Symptoms of large patch disease are orange coloration of the leaf and easy removal of the sheathes from the crowns. As patches expand, there

Corresponding author: K. Kageyama

E-mail: kageyama@cc.gifu-u.ac.jp

Accepted for publication 5 October 1998.

Publication no. D-1998-1214-04R

(C) 1999 The American Phytopathological Society is an orange coloration of the margin. If the disease is severe, all of the grass is killed, leaving a bare patch.

Kobayashi (23) studied the relationships between the occurrence of large patch disease and the isolation frequency of Fusarium roseum, Curvularia spp., Helminthosporium spp., and $R$. solani from diseased plants. He suggested that large patch disease severity may be increased by combined infection with $F$. roseum, Curvularia spp., and Helminthosporium spp. Green et al. (8) isolated binucleate Rhizoctonia spp., Ophiospharella herpotricha, Gaeumannomyces incrustans, several unidentified ectotrophs, and $R$. solani AG2-2 from zoysia grass showing large patch symptoms, and suggested that $R$. solani AG2-2 and $O$. herpotricha caused patch symptoms. However, because of the low isolation frequency of $O$. herpotricha, it is probably not the primary pathogen.

Recent studies of Pythium flora from turfgrasses showed that pathogenic and nonpathogenic species are common in both diseased $(1,11,29)$ and healthy turf (32). $P$. vanterpoolii (18), P. aristosporum (19), $P$. graminicola (20), and $P$. periplocum (21) were reported to be pathogenic to zoysia grass. In preliminary experiments, $P$. periplocum and $P$. vanterpoolii were isolated with $R$. solani AG2-2 LP from zoysia grass showing large patch disease symptoms $(3,25)$, suggesting that Pythium species might be associated with intensi- fication of large patch disease of zoysia grass.

The purposes of this study were (i) to isolate and identify Pythium species associated with large patch disease of zoysia grass, and (ii) to determine the effect of Pythium species in a complex with $R$. solani AG2-2 LP on large patch disease.

\section{MATERIALS AND METHODS}

Isolate collection and identification of Pythium species. Samples of zoysia grass (Zoysia matrella), with or without symptoms of large patch, were collected from nine sites from five golf courses with histories of large patch in Gifu, Hyogo, and Kyoto from 1991 to 1995. Sod samples (10 $\mathrm{cm}$ diameter, 5 to $10 \mathrm{~cm}$ depth) were taken from the margins of expanding patches with a golf course hole cutter.

Isolation of Pythium species was attempted from sheath tissue, thatch, and rhizosphere soil. Twenty pieces of sheath tissue and thatch were collected from each sod sample, washed in tap water, blotted dry, placed on the modified Pythium selective medium (AP) described by Kageyama and Ui (22) (cornmeal agar [CMA] plus $100 \mathrm{mg}$ of agrimycin and $5 \mathrm{mg}$ of pimaricin per liter), and incubated at $25^{\circ} \mathrm{C}$ in darkness. To isolate from rhizosphere soil, $1 \mathrm{~g}$ of air-dried, sieved soil was suspended in $100 \mathrm{ml}$ of $0.35 \%$ Bacto agar (Difco Laboratories, Detroit, MI) mixed with 100 $\mathrm{ml}$ of water. After shaking for $30 \mathrm{~min}, 1 \mathrm{ml}$ of the soil suspension was spread over $\mathrm{VP}_{3}$ medium containing $20 \mathrm{~g}$ of sucrose, $10 \mathrm{mg}$ of $\mathrm{CaCl}_{2}, 10 \mathrm{mg}$ of $\mathrm{MgSO}_{4} \cdot 7 \mathrm{H}_{2} \mathrm{O}, 1 \mathrm{mg}$ of $\mathrm{ZnCl}_{2}, 0.02 \mathrm{mg}$ of $\mathrm{CuSO}_{4} \cdot 5 \mathrm{H}_{2} \mathrm{O}, 0.02 \mathrm{mg}$ of $\mathrm{MoO}_{3}, 0.02 \mathrm{mg}$ of $\mathrm{MnCl}_{2}, 0.02 \mathrm{mg}$ of $\mathrm{FeSO}_{4} \cdot 7 \mathrm{H}_{2} \mathrm{O}, 0.1 \mathrm{mg}$ of thiamine $\mathrm{HCl}, 17$ $\mathrm{g}$ of CMA, $23 \mathrm{~g}$ of Bacto agar, $5 \mathrm{mg}$ of pimaricin, $75 \mathrm{mg}$ of vancomycin, $50 \mathrm{mg}$ of penicillin, $25 \mathrm{mg}$ of PCNB, $2.5 \mathrm{mg}$ of rose bengal, and 1 liter of distilled water (2). After 40- to 48-h incubation in darkness at $20^{\circ} \mathrm{C}$, the soil suspension was washed off the surface of the plates under slowly running tap water. The plates were incubated for another $24 \mathrm{~h}$ to allow any slowergrowing Pythium colonies to develop. Colonies resembling Pythium were transferred to the AP medium.

After a 2-day incubation in darkness at $25^{\circ} \mathrm{C}$, hyphal tips of Pythium colonies were transferred to the AP medium to eliminate bacterial contamination. After another 2-day incubation under the same conditions, Pythium colonies were trans- 
ferred to CMA slants. Isolates were identified based on their morphological characteristics on CMA and on pieces of colonized grass in water (36) according to the key of van der Plaats-Niterink (35).

Isolation and identification of $R$. solani AG2-2 LP. Rhizoctonia species also were isolated from sheath tissue, thatch, and rhizosphere soil. Twenty pieces of sheath tissue and thatch were cut from each sod sample, washed in tap water, blotted dry, and placed on $2 \%$ acidified water agar (AWA) adjusted to a $\mathrm{pH}$ between 4 and 5 with $10 \%$ lactic acid. To isolate Rhizocto-

Table 1. Geographic and host sources of the isolates of Pythium and Rhizoctonia species used in this study

\begin{tabular}{llll}
\hline Species & Isolates & \multicolumn{1}{c}{ Original host } & Geographic origin \\
\hline P. periplocum & AS8-5-9V & Zoysia grass rhizosphere soil & Gifu \\
& AS9-5-8S & Zoysia grass & Gifu \\
& DS1-7-2S & Zoysia grass & Gifu \\
& MK4-7-4S & Zoysia grass & Gifu \\
& S6-8-30D & Soil of golf course & Gifu \\
P. rostratum & AMON-6-8S & Zoysia grass & Gifu \\
& AS9-5-1V & Zoysia grass rhizosphere soil & Gifu \\
& MK2-1-9S & Zoysia grass & Gifu \\
& MK2-6-9S & Zoysia grass & Gifu \\
& AS5-8-3S & Bentgrass & Gifu \\
& AS7-9-1V & Bentgrass rhizosphere soil & Gifu \\
& DS1-5-2T & Thatch of zoysia grass & Gifu \\
& K4-6-5T & Thatch of zoysia grass & Gifu \\
& TJul37 & Carrot & Gifu \\
& AJ2-4-10 & Zoysia grass & Gifu \\
& AS2-2-5V & Zoysia grass rhizosphere soil & Gifu \\
& AS5-5-4S & Bentgrass & Gifu \\
& DK1-6-3D & Zoysia grass rhizosphere soil & Gifu \\
& K4-6-8D & Zoysia grass rhizosphere soil & Gifu \\
& 48R & Zoysia grass & Kyoto \\
& AS8-5-1T & Thatch of zoysia grass & Gifu \\
& AS9-4-1T & Thatch of zoysia grass & Gifu \\
& AS9-4-3S & Zoysia grass & Gifu \\
& DS1-7-5S & Zoysia grass & Gifu \\
& MK4-7-3S & Zoysia grass & Gifu \\
\hline
\end{tabular}

${ }^{\mathrm{z}}$ Origins listed are in Japan. nia species from soil, $50 \mathrm{~g}$ of air-dried rhizosphere soil were put into petri dishes, and 2-cm-long stem segments of flax sterilized with propylene oxide were inserted vertically (20 per petri dish) into the soil and incubated in darkness at $25^{\circ} \mathrm{C}$. After 2 days, the segments were removed, washed, blotted, and placed on AWA. After a 2-day incubation in darkness at $25^{\circ} \mathrm{C}$, hyphal tips of Rhizoctonia species were transferred again to AWA to obtain pure cultures. After incubating for another 2 days on AWA at $25^{\circ} \mathrm{C}$ in darkness, hyphal tips were transferred to potato dextrose agar (PDA) slants.

$R$. solani AG2-2 LP isolates were identified on the basis of cultural characteristics, hyphal anastomosis, and the number of nuclei per cell. The cultures were evaluated for mycelial color, sclerotial formation, zonation, and aerial mycelium after incubating 4 weeks on PDA at $25^{\circ} \mathrm{C}$ in darkness. For observing hyphal anastomosis, isolates with the same cultural characteristics were paired on a clean glass slide with the $R$. solani AG2-2 LP tester isolate (48R) stocked in our laboratory (16) according to the method reported by Kronland and Stanghellini (24). The slides were placed in a moist chamber and incubated at $25^{\circ} \mathrm{C}$ for 24 to $48 \mathrm{~h}$. The overlapping hyphae were stained with $0.5 \%$ safranin $\mathrm{O}$ in distilled water and $3 \% \mathrm{KOH}$ according to the method reported by Bandoni (5) and covered with a coverslip. Hyphal branches of the stained area were microscopically

Table 2. Isolation of Pythium spp. and Rhizoctonia solani AG2-2 LP from zoysia grass with a history of large patch disease for 5 years

\begin{tabular}{|c|c|c|c|c|c|c|c|c|c|c|c|c|c|c|c|c|c|c|c|c|}
\hline \multirow[b]{3}{*}{ Month $^{r}$} & \multirow{3}{*}{$\begin{array}{c}\text { Sod } \\
\text { samples }\end{array}$} & \multicolumn{18}{|c|}{ Number of isolates } & \multirow{3}{*}{$\begin{array}{l}\text { Pythium } \\
\text { spp. }\end{array}$} \\
\hline & & \multicolumn{3}{|c|}{ P. periplocum } & \multicolumn{3}{|c|}{ P. rostratum } & \multicolumn{3}{|c|}{ P. torulosum } & \multicolumn{3}{|c|}{ P. vanterpoolii } & \multicolumn{3}{|c|}{ Others $^{s}$} & \multicolumn{3}{|c|}{ R. solani ${ }^{\mathrm{t}}$} & \\
\hline & & $\mathbf{P}^{\mathbf{u}}$ & $\mathbf{T}^{\mathbf{v}}$ & $\mathbf{S}^{\mathbf{w}}$ & $\mathbf{P}^{\mathbf{u}}$ & $\mathbf{T}^{\mathbf{v}}$ & $\mathbf{S}^{\mathbf{w}}$ & $\mathbf{P}^{\mathbf{u}}$ & $\mathbf{T}^{\mathbf{v}}$ & $\overline{\mathbf{S}^{\mathbf{w}}}$ & $\mathbf{P u}^{\mathbf{u}}$ & $T^{v}$ & $\mathbf{S}^{\mathbf{w}}$ & $\overline{\mathbf{P u}^{\mathbf{u}}}$ & $\mathbf{T}^{\mathbf{v}}$ & $\overline{\mathbf{S}^{\mathbf{w}}}$ & $\mathbf{P}^{\mathbf{x}}$ & $\mathbf{T}^{\mathbf{y}}$ & $\overline{\mathbf{S}^{\mathbf{z}}}$ & \\
\hline January & 10 & & 1 & 4 & & & 4 & 14 & 3 & 6 & & & 4 & 10 & 9 & 13 & 2 & & & 68 \\
\hline February & 10 & 1 & 9 & 2 & & & 1 & 4 & 25 & 9 & 3 & & 7 & 22 & 7 & 15 & 7 & & & 105 \\
\hline March & 7 & & & 4 & & 3 & 2 & 10 & 18 & 24 & & & 4 & 5 & 3 & 4 & 8 & 1 & 1 & 77 \\
\hline April & 14 & 3 & 3 & 8 & 13 & & 2 & 31 & 15 & 4 & 10 & & & 21 & 4 & 12 & 121 & 28 & 8 & 126 \\
\hline May & 19 & 63 & 14 & 33 & 4 & 4 & 1 & 37 & 37 & 45 & 2 & & & 5 & 1 & 20 & 204 & 18 & 47 & 266 \\
\hline June & 5 & 20 & 12 & 5 & 10 & 3 & 2 & 6 & 5 & 12 & & & & 13 & 5 & & 7 & 7 & 1 & 93 \\
\hline July & 5 & 15 & 1 & 15 & 1 & & 2 & 14 & 37 & 37 & & & 1 & 2 & & & 5 & 1 & & 125 \\
\hline August & 5 & 1 & 10 & 2 & & & & 9 & 20 & 23 & & 1 & & 1 & 1 & 5 & & & & 73 \\
\hline September & 5 & 1 & & & & & & 3 & 12 & 3 & & & & 1 & 2 & 1 & & & 1 & 23 \\
\hline October & 9 & 4 & 8 & 13 & & & & 3 & 2 & 3 & 5 & 2 & 26 & 25 & 14 & 14 & 12 & & 1 & 119 \\
\hline November & 8 & 3 & 1 & 1 & 28 & 4 & 7 & 20 & 3 & 10 & & & 3 & 28 & 8 & 10 & 28 & 8 & & 126 \\
\hline December & 10 & & 1 & 1 & & & 2 & 2 & 6 & 3 & & & 4 & 11 & 14 & 35 & 37 & 3 & & 79 \\
\hline & & 111 & 60 & 88 & 56 & 14 & 23 & 153 & 183 & 179 & 20 & 3 & 49 & 144 & 68 & 129 & 431 & 66 & 59 & \\
\hline Totals & 107 & & 259 & & & 93 & & & 515 & & & 72 & & & 341 & & & 556 & & 1,280 \\
\hline
\end{tabular}

${ }^{\mathrm{r}}$ Isolation from five golf courses in Gifu, Hyogo, and Kyoto for 1992 to 1996.

${ }^{\text {s }}$ The others included $P$. dissotocum, $P$. iwayamai, $P$. periilum, $P$. spinosum, $P$. sylvaticum, and unidentified Pythium that did not produce reproductive structures.

${ }^{\mathrm{t}}$ All R. solani were belonged to AG2-2 LP.

u Total number of isolates each month for 5 years obtained from plants of zoysia grass. Twenty pieces of sheath tissues were cut from sod samples and placed on the Pythium selective medium at every sampling time.

$\checkmark$ Total number of isolates each month for 5 years obtained from thatch of zoysia grass. Twenty pieces of thatch were cut from sod samples and placed on the Pythium selective medium at every sampling time.

${ }^{w}$ Total number of isolates each month for 5 years obtained from rhizosphere soil of zoysia grass. One $\mathrm{g}$ of air-dried, sieved soil was suspended in $100 \mathrm{ml}$ of $0.35 \%$ Bacto agar, and $1 \mathrm{ml}$ of the soil suspension was spread over the Pythium selective medium $\left(\mathrm{VP}_{3}\right)$ at every sampling time.

$\mathrm{x}$ Total number of isolates each month for 5 years obtained from sheath tissue of zoysia grass. Twenty pieces of sheath tissue were cut from sod samples and placed on acid water agar at every sampling time.

${ }^{y}$ Total number of isolates each month for 5 years obtained from thatch of zoysia grass. Twenty pieces of thatch were cut from sod samples and placed on acid water agar at every sampling time.

${ }^{\mathrm{z}}$ Total number of isolates each month for 5 years obtained from rhizosphere soil of zoysia grass. Fifty g of rhizosphere soil were put into petri dishes. Twenty segments of baiting flax were incubated in the soil for 2 days and placed on acid water agar after washing in tap water at every sampling time. 
observed for the number of nuclei and the presence of anastomosis with the tester isolate. The number of nuclei per cell was based on observation of 15 cells. All observations were conducted at least twice.

Isolates of $R$. solani from zoysia grass showed an irregular cluster of mycelia (not sclerotia), an irregular zonation, dark brown main hyphae, and some aerial hyphae on PDA after a 4-week incubation. Isolates grew at temperatures ranging from 10 to $30^{\circ} \mathrm{C}$, and the optimum temperature was $23^{\circ} \mathrm{C}$. These characteristics were different from $R$. solani AG2-2 IIIB and AG2-2 IV. Based on these characteristics, the isolates were identified as AG2-2 LP.

Pathogenicity of Pythium species and Rhizoctonia solani AG2-2 LP to zoysia grass. Four isolates of $P$. periplocum, $P$. rostratum, $P$. torulosum, $P$. vanterpoolii, and $R$. solani AG2-2 LP were tested for pathogenicity to zoysia grass (Table 1). Sod samples used in tests were collected from zoysia grass on golf courses and then transferred to plastic pots $(10 \mathrm{~cm}$ diameter and $5 \mathrm{~cm}$ depth). Inoculum was produced by transferring PDA mycelial plugs of each isolate to $300-\mathrm{ml}$ flasks containing $4 \mathrm{~g}$ of autoclaved bentgrass seed in addition to about $20 \mathrm{ml}$ water according to Tojo et al. (34). After 10 days, the colonized seeds were mixed with $20 \mathrm{~g}$ of autoclaved ovendried soil with a mortar and a pestle. Five $g$ of inoculum was spread evenly over each pot and rubbed in at crown level after cutting the grass to a $1.0-\mathrm{cm}$ height with scissors. Plants were maintained in a growth chamber at 15 to $20^{\circ} \mathrm{C}$. Disease symptoms were visually estimated 14 days after inoculation on a scale of 0 to 4 , where $0=$ healthy, $1=1$ to $25 \%$ of sod diseased, $2=26$ to $50 \%$ diseased, $3=51$ to $75 \%$ diseased, and $4=76$ to $100 \%$ diseased. Disease severity was calculated as:

Disease severity $=\Sigma($ disease index $\times$ number of sod samples in each index $) /(4 \times$ total number of sod samples ) $\times 100$

Treatments consisted of three replicate pots, and the experiments were conducted twice. Isolation was made from five pieces of sheath tissue from each pot on AWA for $R$. solani AG2-2 LP and AP for each $P y$ thium species.

Coinoculation of Pythium species with $R$. solani AG2-2 LP and chemical treatment of zoysia grass. The effects of $R$. solani AG2-2 LP inoculated alone and of Pythium species inoculated alone and in combination with $R$. solani AG2-2 LP on zoysia grass were examined. Inoculum of each isolate or combination of isolates was rubbed over sod at the rate of $5 \mathrm{~g}$ of inoculum per pot. The production of inoculum, the maintenance of the sod, and the disease rating scale were the same as described in the previous experiments. Disease severity was visually estimated 14 days after inoculation. All treatments were replicated three times in each trial.
Data analysis. Values of disease severity were arcsine-transformed prior to statistical analysis. After analysis of variance (ANOVA), Duncan's multiple range test was done to separate means at a significance level of $P=0.05$.

\section{RESULTS}

Isolation and identification of Pythium species and $R$. solani AG2-2 LP. A total of 1,280 Pythium isolates was obtained from the sites with a history of large patch disease of zoysia grass in Gifu, Hyogo, and Kyoto (Table 2). Four hundred and eightyfour (37.8\%) and $328(25.6 \%)$ isolates were obtained from sheath tissue and thatch, respectively, and 468 isolates $(36.6 \%)$ were obtained from rhizosphere soil using the soil dilution plate method.

$P$. periplocum accounted for 259 isolates $(20.2 \%)$ and was frequently recovered from May to July. The numbers of $P$. rostratum and $P$. vanterpoolii isolates were 93 (7.3\%) and 72 (5.6\%), respectively. $P$. torulosum was the most prevalent Pythium species $(40.2 \%)$. Other Pythium spp. accounted for 341 isolates $(26.6 \%)$, consisting of $P$. dissotocum, $P$. iwayamai, $P$. periilum, $P$. spinosum, $P$. sylvaticum, and unidentified isolates that did not produce reproductive structures.

A total of 556 isolates of $R$. solani AG22 LP was obtained from sites with a history of large patch disease of zoysia grass in Gifu, Hyogo, and Kyoto over a period of 5

Table 3. Isolation of Rhizoctonia solani AG2-2 LP, Pythium periplocum, P. rostratum, P. torulosum, and P. vanterpoolii from zoysia grass with large patch symptoms on several golf courses

\begin{tabular}{|c|c|c|c|c|c|c|c|c|c|c|c|c|c|c|c|c|c|c|c|c|c|}
\hline \multirow[b]{2}{*}{ Species } & \multicolumn{21}{|c|}{ Isolation (\% or CFU) } \\
\hline & $\mathbf{A}^{\mathbf{t}}$ & B & $\mathrm{C}$ & D & $\mathbf{E}$ & $\mathbf{F}$ & G & $\mathbf{H}$ & I & $\mathbf{J}$ & $\mathbf{K}$ & $\mathbf{L}$ & $\mathbf{M}$ & $\mathbf{N}$ & $\mathbf{O}$ & $\mathbf{P}$ & $\mathbf{Q}$ & $\mathbf{R}$ & $\mathbf{S}$ & $\mathbf{T}$ & $\overline{\mathbf{U}}$ \\
\hline \multicolumn{22}{|c|}{ R. solani AG2-2 LP } \\
\hline Plant $\mathrm{u}^{\mathrm{u}}$ & 15 & 20 & 10 & 90 & 40 & 35 & 60 & 30 & 45 & 55 & 35 & 20 & 60 & 10 & 35 & 20 & 80 & 5 & 10 & 30 & 70 \\
\hline Thatch $^{v}$ & & 20 & 5 & & & & 30 & 20 & 20 & & & & 20 & & 85 & & 30 & & & 20 & 10 \\
\hline Soil $^{\mathrm{w}}$ & & 5 & & & & & & 5 & & & & 5 & 15 & & 5 & & 5 & & & & 45 \\
\hline \multicolumn{22}{|c|}{ P. periplocum } \\
\hline Plant $^{\mathrm{x}}$ & 10 & & 10 & & & & & 40 & 5 & 5 & & & & & & & & & & 40 & 5 \\
\hline Thatch $^{y}$ & & 10 & & & & & & 15 & & & & & & 10 & & & & 70 & & 15 & \\
\hline Soil $^{\mathrm{z}}$ & & 40 & & & & & 30 & 310 & 20 & 70 & & & 10 & & & 10 & 30 & 20 & & & \\
\hline \multicolumn{22}{|c|}{ P. rostratum } \\
\hline Plant $^{\mathrm{x}}$ & & & 5 & & & & & & & & & & 5 & & & & & & & & 20 \\
\hline Thatch $^{y}$ & & & & & & & & 5 & & & & & & & & & & & & 5 & \\
\hline Soil $^{\mathrm{z}}$ & & & 10 & & & & & & & & & & & & & & & & 50 & & 10 \\
\hline \multicolumn{22}{|c|}{ P. torulosum } \\
\hline Plant $^{\mathrm{x}}$ & & & 15 & 5 & & & & 15 & & & & 20 & & 30 & & & 10 & & & 15 & 10 \\
\hline Thatch $^{y}$ & & & 25 & & & & 5 & 10 & & & & & 10 & 10 & & & & & & 10 & \\
\hline Soil $^{\mathrm{z}}$ & 70 & & 10 & & & & 180 & 60 & & & & & & 20 & & & & & & & \\
\hline \multicolumn{22}{|c|}{$P$. vanterpoolii } \\
\hline Plant $^{\mathrm{x}}$ & & & & 5 & & 10 & & 40 & & & 10 & & & & & 10 & & & & & 10 \\
\hline Thatch $^{y}$ & & & & & & & & & & & & & & & & & & & & & \\
\hline Soil $^{\mathrm{z}}$ & & & 10 & & & & & & & 230 & & & & & & & & & & & \\
\hline \multicolumn{22}{|c|}{$\begin{array}{l}\text { Twenty-one (A to U) sod samples of zoysia grass with large patch symptoms, which were collected from five golf courses in Gifu, Hyogo, and Kyoto for } \\
1992 \text { to } 1996 \text {. }\end{array}$} \\
\hline \multirow{2}{*}{\multicolumn{22}{|c|}{$\begin{array}{l}\text { Twenty pieces of sheath tissue were cut from sod and placed on acid water agar at every sampling time. } \\
\text { v Twenty pieces of thatch were cut from sod and placed on acid water agar at every sampling time. }\end{array}$}} \\
\hline & & & & & & & & & & & & & & & & & & & & & \\
\hline \multicolumn{22}{|c|}{$\begin{array}{l}\text { wifty g of rhizosphere soil were put into petri dishes. Twenty segments of baiting flax were incubated in the soil for } 2 \text { days, and placed on acid water agar } \\
\text { after washing in tap water at every sampling time. }\end{array}$} \\
\hline \multirow{2}{*}{\multicolumn{22}{|c|}{$\begin{array}{l}\text { x Twenty pieces of sheath tissue were cut from sod and placed on the Pythium selective medium at every sampling time. } \\
\text { y Twenty pieces of thatch were cut from sod and placed on the Pythium selective medium at every sampling time. }\end{array}$}} \\
\hline & & & & & & & & & & & & & & & & & & & & & \\
\hline${ }^{\mathrm{z}} \mathrm{O}$ & - & & & & & & & ( & & & & & & & & & & & & & \\
\hline
\end{tabular}


years (Table 2). All isolates showed the characteristic mycelial behavior described for Rhizoctonia (33). Four hundred and thirty-one $(77.5 \%)$ and $66(11.9 \%)$ isolates were obtained from sheath tissue and thatch, respectively, and 59 isolates $(10.6 \%)$ were baited from rhizosphere soil with flax. $R$. solani AG2-2 LP isolates were recovered most frequently from April to May.

Isolation of Pythium species and $R$. solani AG2-2 LP from zoysia grass showing large patch symptoms. Twentyone sod samples of zoysia grass with large patch symptoms were collected from five golf courses, and the isolation of Pythium species and $R$. solani AG2-2 LP was perrhizosphere soil (Table 3). R. solani AG2-2 formed from sheath tissue, thatch, and

LP was isolated frequently from all samples, especially from sheath tissue. $P$. periplocum was obtained from 14 sod samples, including from sheath tissue in 7 sod samples, and from thatch or rhizosphere soil in 11 sod samples. $P$. rostratum, $P$. torulosum, and $P$. vanterpoolii were obtained from 6,11 , and 8 sod samples, respectively. A total of 19 sod samples yielded isolates of $R$. solani AG2-2 LP and Pythium spp.; 2 sod samples yielded $R$. solani AG2-2 LP alone.

Pathogenicity tests of Pythium species and $R$. solani AG2-2 LP inoculated individually and in combination on zoysia grass. Isolates of $R$. solani AG2-2 LP were moderately to highly pathogenic to zoysia grass (Table 4). The symptoms induced by

Table 4. Pathogenicity tests of Pythium periplocum, P. rostratum, P. torulosum, P. vanterpoolii, and Rhizoctonia solani AG2-2 LP on zoysia grass

\begin{tabular}{llcc}
\hline Species & Isolates & Disease severity & Reisolation (\%) \\
\hline P. periplocum & AS8-5-9V & $37.5 \mathrm{~b}-\mathrm{f}^{\mathbf{z}}$ & 43.3 \\
& AS9-5-8S & $33.3 \mathrm{~b}-\mathrm{f}$ & 66.7 \\
& MK4-7-4S & $54.2 \mathrm{def}$ & 40.0 \\
P. rostratum & S6-8-30D & $41.7 \mathrm{~b}-\mathrm{f}$ & 20.0 \\
& AMON-6-8S & $12.5 \mathrm{ab}$ & 33.4 \\
& AS9-5-1V & $12.5 \mathrm{a}-\mathrm{d}$ & 30.0 \\
& MK2-1-9S & $12.5 \mathrm{ab}$ & 46.7 \\
P. torulosum & MK2-6-9S & $16.7 \mathrm{abc}$ & 33.4 \\
& AS5-8-3S & $12.5 \mathrm{a}-\mathrm{d}$ & 96.7 \\
& DS1-5-2T & $20.9 \mathrm{a}-\mathrm{e}$ & 56.7 \\
P. vanterpoolii & K4-6-5T & $20.9 \mathrm{a}-\mathrm{e}$ & 96.7 \\
& TJul37 & $16.7 \mathrm{a}-\mathrm{d}$ & 83.4 \\
& AJ2-4-10 & $50.0 \mathrm{c}-\mathrm{f}$ & 46.7 \\
R. solani AG2-2 & LP & $33.3 \mathrm{~b}-\mathrm{f}$ & 26.7 \\
& AS5-5-4S & $41.7 \mathrm{~b}-\mathrm{f}$ & 26.7 \\
& DK1-6-3D & $41.7 \mathrm{~b}-\mathrm{f}$ & 53.4 \\
& K4-6-8D & $70.8 \mathrm{fg}$ & 60.0 \\
Control & AS8-5-1T & $62.5 \mathrm{ef}$ & 63.4 \\
& AS9-4-1T & $62.5 \mathrm{ef}$ & 46.7 \\
\hline
\end{tabular}

y Disease index rated 14 days after inoculation at 15 to $20^{\circ} \mathrm{C}$ using a scale of 0 to 4 , where $0=$ no symptoms apparent and $4=76$ to $100 \%$ of the inoculated area diseased. Disease severity was calculated as: Disease severity $=\Sigma($ disease index $\times$ number of sod samples in each index $) /(4 \times$ total number of sod samples) $\times 100$.

${ }^{z}$ Values within a column having the same letter do not differ significantly $(P<0.05)$ according to Duncan's multiple range test.

Table 5. Pathogenicity tests of Pythium periplocum, P. rostratum, P. torulosum, $P$. vanterpoolii, and Rhizoctonia solani AG2-2 LP, and in combination on zoysia grass

\begin{tabular}{llc}
\hline Species & \multicolumn{1}{c}{ Isolates $^{\mathbf{x}}$} & Disease severity $^{\mathbf{y}}$ \\
\hline P. periplocum & DS1-7-2S & $47.2 \mathrm{c}^{\mathrm{z}}$ \\
P. periplocum + AG2-2 LP & DS1-7-2S + AS9-4-3S & $72.2 \mathrm{e}$ \\
P. rostratum & MK2-6-9S & $8.3 \mathrm{a}$ \\
P. rostratum + AG2-2 LP & MK2-6-9S + AS9-4-3S & $63.9 \mathrm{de}$ \\
P. torulosum & AS7-9-1V & $27.8 \mathrm{~b}$ \\
P. torulosum + AG2-2 LP & AS7-9-1V + AS9-4-3S & $83.3 \mathrm{f}$ \\
P. vanterpoolii & AJ2-4-10 & $54.2 \mathrm{c}$ \\
P. vanterpoolii + AG2-2 LP & AJ2-4-10 + AS9-4-3S & $72.2 \mathrm{e}$ \\
AG2-2 LP & AS9-4-3S & $66.7 \mathrm{e}$ \\
AG2-2 LP + uninfested inoculum & AS9-4-3S & $55.6 \mathrm{~cd}$ \\
Control & - & $0.0 \mathrm{a}$ \\
\hline
\end{tabular}

${ }^{\mathrm{x}}$ Two-organism treatments were inoculated at the same time.

y Means of three trials with three replications. Disease index was estimated using a scale of 0 to 4 , where $0=$ no symptoms apparent and $4=76$ to $100 \%$ of the inoculated area diseased. Disease severity was calculated as: Disease severity $=\Sigma$ (disease index $\times$ number of sod samples in each index $) /(4 \times$ total number of sod samples $) \times 100$.

${ }^{\mathrm{z}}$ Means carrying same letters in a column are not significantly different $(P=0.05)$ according to Duncan's multiple range test.
$R$. solani AG2-2 LP alone induced an orange color of the sheath tissue, and sheaths were easily removed from crowns. These symptoms are the same as those observed with large patch disease on golf courses. All isolates of $P$. rostratum were nonpathogenic, and those of $P$. torulosum caused little or no disease. Isolates of P. periplocum and $P$. vanterpoolii were moderately aggressive. The main symptom caused by Pythium spp. was leaf chlorosis and was different from symptoms on turf affected by large patch on golf courses.

Disease was more severe with coinoculation of $R$. solani AG2-2 LP and P. torulosum than with inoculation of $R$. solani AG2-2 LP alone (Table 5). Symptoms caused by the combination were similar to those of $R$. solani AG2-2 LP alone, but they developed more rapidly. The coinoculation of $R$. solani AG2-2 LP and $P$. periplocum or $P$. vanterpoolii did not significantly increase disease severity, but the symptoms induced necrosis of crown tissue and then sheath rotting. Finally, all plants died and the foliar tissue decomposed. The inoculated fungi were always reisolated from sheath tissue of zoysia grass. All uninoculated plants remained healthy.

\section{DISCUSSION}

In warm-season turfgrasses, $R$. solani AG2-2 LP is a causal agent of large patch disease $(16,17)$ and has been isolated from centipede grass (10), St. Augustine's grass $(10,15)$, and zoysia grass $(3,4,8,23)$. In the present study, in addition to $R$. solani AG22 LP, $P$. dissotocum, $P$. iwayamai, $P$. periilum, $P$. periplocum, $P$. rostratum, $P$. spinosum, $P$. sylvaticum, $P$. torulosum, $P$. vanterpoolii, and several unidentified Pythium spp. that did not produce reproductive structures were obtained from zoysia grass showing large patch symptoms. $P$. periplocum, $P$. rostratum, $P$. torulosum, and $P$. vanterpoolii were the primary species isolated, but only $P$. periplocum and $P$. vanterpoolii were pathogenic to zoysia grass. $P$. torulosum was a predominant species in turf $(1,29,32)$ but caused little or no disease to zoysia grass (18). P. periplocum was the second most frequently isolated species. Results from Ichitani et al. (21) and the current study indicated that $P$. periplocum is moderately aggressive on zoysia grass. There is no prior report of the association of $P$. rostratum with zoysia grass disease. Although the fungus has been isolated from turfgrass, it was nonpathogenic to zoysia grass $(1,11,32)$. $P$. vanterpoolii is a causal agent of spring dead spot of zoysia grass (18) and Pythium blight of bentgrass (Agrostis palustris) $(1,18,28,29)$. Our results confirmed that $P$. vanterpoolii is moderately aggressive on zoysia grass. P. aphanidermatum (1,7,9, 29,32), P. aristosporum $(1,19,29)$, P. arrhenomanes $(1,13,14), P$. graminicola $(1,13$, 14,20,21,28,29,35), P. myriotylum (1), and 
P. ultimum $(1,26,27)$, which have been previously described as causal agents of turfgrass disease, were not isolated in the present study.

Since $P$. torulosum is not pathogenic to zoysia grass (21), there is no information on the association with zoysia grass; nevertheless, the fungus is a predominant species. In the present study, $P$. torulosum frequently was isolated from thatch and soil as well as from plant tissues over all seasons, indicating that it will survive saprophytically. However, the coinoculation of $P$. torulosum and $R$. solani AG 2-2 LP induced more severe disease than did the single inoculation of $R$. solani AG2-2 LP. These results suggest that the fungus will change habit from saprophytic to parasitic in large patch occurrence and may act synergistically with $R$. solani to affect zoysia grass. Further study is needed on the interaction between $P$. torulosum and $R$. solani AG 2-2 LP.

In contrast, $P$. periplocum and $P$. vanterpoolii are considered to be active as parasites during large patch occurrence but otherwise dormant, since the fungi frequently were isolated from plant tissues during disease occurrence but not in other seasons. The coinoculation of $R$. solani AG 2-2 LP and P. periplocum or $P$. vanterpoolii did not significantly increase the disease. However, both fungi intensified symptoms of the disease, resulting in bare patch symptoms. The symptoms observed were similar to those of turf with severe large patch on golf courses where drainage is poor. In such sites, the turf cannot recover, although large patch symptoms generally become unclear as the growth of zoysia grass becomes active in summer.

$P$. periplocum has been reported to control damping-off of cucumber caused by $P$. aphanidermatum (12), and mycoparastism of $R$. solani by $P$. periplocum is known (31). However, $P$. periplocum enhanced disease severity when combined with $R$. solani AG2-2 LP and was frequently isolated from diseased plants together with $R$. solani AG2-2 LP. It appears that $P$. periplocum may act synergistically with $R$. solani AG2-2 LP.

\section{ACKNOWLEDGMENTS}

This study was supported in part by a Grant-inaid for Research (No. 07556015) from the Ministry of Education, Science and Culture of Japan. We thank Toshihiro Hasegawa and Tatsuo Hori at Fuji Country Co. Ltd. for their efforts in this project, and Brion Duffy for correcting the English in the manuscript.

\section{LITERATURE CITED}

1. Abad, Z. G., Shew, H. D., and Lucas, L. T. 1994. Characterization and pathogenicity of Pythium species isolated from turfgrass with symptoms of root and crown rot in North
Carolina. Phytopathology 84:913-921.

2. Ali-Shtayeh, S. M., Ho, C. L., and Dick, M. W. 1986. An improved method and medium for quantitative estimates of populations of Pythium species from soil. Trans. Br. Mycol. Soc. 86:39-47.

3. Aoyagi, T., Kageyama, K., Hasegawa, T., Hori, T., and Hyakumachi, M. 1995. Pythium periplocum and $P$. vanterpoolii might be associated with intensifying large patch disease of zoysiagrass. (Abstr. in Japanese.) Ann. Phytopathol. Soc. Jpn. 61:626-627.

4. Aoyagi, T., Kageyama, K., and Hyakumachi, M. 1998. Characterization and survival of Rhizoctonia solani AG2-2 LP associated with large patch disease of zoysia grass. Plant Dis. 82:857-863.

5. Bandoni, R. J. 1979. Safranin O as a rapid stain for fungi. Mycologia 71:873-874.

6. Couch, H. B. 1995. Rhizoctonia blight of warm season turfgrasses. Pages 33-36 in: Diseases of Turfgrasses. 3rd ed. Krieger Publishing Company, Malabar, FL.

7. Endo, R. M. 1961. Turfgrass disease in southern California. Plant Dis. Rep. 45:869-873.

8. Green, D. E., II, Fry, J. D., Pair, J. C., and Tisserat, N. A. 1993. Pathogenicity of Rhizoctonia solani AG-2-2 and Ophiosphaerella herpotricha on zoysiagrass. Plant Dis. 77:1040-1044.

9. Hall, T. J., Larsen, P. O., and Schmitthenner, A. F. 1980. Survival of Pythium aphanidermatum in golf course turfs. Plant Dis. 64:1100-1103.

10. Haygood, R. A., and Martin, S. B. 1990. Characterization and pathogenicity of species of Rhizoctonia associated with centipedegrass and St. Augustinegrass in South Carolina. Plant Dis. 74:510-514.

11. Hendrix, F. F., Campbell, W. A., and Moncrief, J. B. 1970. Pythium species associated with golf turfgrasses in the south and southeast. Plant Dis. Rep. 54:419-421.

12. Hockenhull, J., Jensen, D. F., and Yudiarti, T. 1992. The use of Pythium periplocum to control of cucumber seedlings caused by Pythium aphanidermatum. Pages 203-206 in: Biological Control of Plant Disease E. S. Tjamos, G. C. Papavizas, and R. J. Cook, eds. Plenum Press, New York.

13. Hodges, C. F., and Campbell, D. A. 1994. Infection of adventitious roots of Agrostis palustris by Pythium species at different temperature regimes. Can. J. Bot. 72:378-383.

14. Hodges, C. F., and Coleman, L. W. 1985. Pythium-induced root dysfunction of secondary roots of Agrostis palustris. Plant Dis. 69:336-340.

15. Hurd, B., and Grisham, M. P. 1983. Rhizoctonia spp. associated with brown patch of Saint Augustinegrass. Phytopathology 73:16611665 .

16. Hyakumachi, M., Mushika, T., Ogiso, Y., Toda, T., Kageyama, K., and Tsuge, T. 1998. Characterization of a new cultural type LP of Rhizoctonia solani AG 2-2 isolated from warm season turfgrasses, and its genetic differentiation from other cultural types. Plant Pathol. 47:1-9.

17. Hyakumachi, M., Ogiso, Y., Kageyama, K., and Tsuge, T. 1994. Difference between large patch fungus isolated from Zoysia japonica and cultural type IV both belonging to Rhizoctonia solani AG2-2. (Abstr. in Japanese.) Ann. Phytopathol. Soc. Jpn. 60:344.

18. Ichitani, T., Kang, H. T., and Mine, K. 1989. Materials for Pythium flora of Japan. (II) Pythium torulosum and $P$. vanterpoolii from golfgreens of manilagrass or bentgrass. Bull. Univ. Osaka Pref., Ser. B. 41:9-19.

19. Ichitani, T., and Kinoshita, T. 1990. Materials for Pythium flora of Japan. (III) Pythium aristosporum from rhizosphere soil of zoysia green. Bull. Univ. Osaka Pref., Ser. B. 42:1-8.

20. Ichitani, T., and Kinoshita, T. 1991. Materials for Pythium flora of Japan. (IV) Pythium graminicola from rhizosphere soil of zoysia green. Bull. Univ. Osaka Pref., Ser. B. 43:1-9.

21. Ichitani, T., Tani, T., and Umakoshi, T. 1986. Identification of Pythium spp. pathogenic on manila grass. Trans. Mycol. Soc. Jpn. 27:4150.

22. Kageyama, K., and Ui, T. 1980. A selective medium for isolation of Pythium spp. Ann. Phytopathol. Soc. Jpn. 46:542-544.

23. Kobayashi, K. 1980. Studies on Rhizoctonia large patch of zoysia turfgrass (I). J. Japanese Soc. Turfgrass Sci. 9:119-125.

24. Kronland, W. C., and Stanghellini, M. E. 1988. Clean slide technique for the observation of anastomosis and nuclear condition of Rhizoctonia solani. Phytopathology 78:820822.

25. Matsuyama, J., Yamada, A., Hori, T. Kageyama, K., and Hyakumachi, M. 1993 Rhizoctonia spp. and Pythium spp. isolated from large patch and brown patch disease of turfgrasses. (Abstr. in Japanese.) Ann. Phytopathol. Soc. Jpn. 59:750.

26. Moore, L. D., and Couch, H. B. 1961. Pythium ultimum and Helminthosporium vagans as foliar pathogens of Graminae. Plant Dis. Rep. 45:616-619.

27. Moore, L. D., Couch, H. B., and Bloom, J. R. 1963. Influence of environment on disease of turfgrasses. III. Effect of nutrition, $\mathrm{pH}$, soil temperature, air temperature, and soil moisture on Pythium blight of Highland bentgrass. Phytopathology 53:53-57.

28. Muse, R. R., Schmitthenner, A. F., and Partyka, R. E. 1974. Pythium species associated with foliar blighting of creeping bentgrass. Phytopathology 64:252-253.

29. Nelson, E. B., and Craft, C. M. 1991. Identification and comparative pathogenicity of $P y$ thium spp. from roots and crowns of turfgrasses exhibiting symptoms of root rot. Phytopathology 81:1529-1536.

30. Oniki, M., Kobayashi, K., Araki, T., and Ogoshi, A. 1986. A new disease of turf-grass caused by binucleate Rhizoctonia AG-Q. Ann. Phytopathol. Soc. Jpn. 52:850-853.

31. Ribeiro, W. R. C., and Butler, E. E. 1995. Comparison of the mycoparasites Pythium periplocum, $P$. accanthicum and $P$. oligandrum. Mycol. Res. 99:963-969.

32. Saladini, J. L., Schmitthenner, A. F., and Larsen, P. O. 1983. Prevalence of Pythium species associated with cottony-blighted and healthy turfgrasses in Ohio. Plant Dis. 67:517-519.

33. Sneh, B., Burpee, L., and Ogoshi, A. 1991 Identification of Rhizoctonia Species. American Phytopathological Society, St. Paul, MN.

34. Tojo, M., Fujita, Y., Awad, H. M., and Ichitani, T. 1993. Preparation of Pythium inocula using bentgrass seeds for glasshouse studies. Proc. Kansai Plant Prot. 35:1-5.

35. van der Plaats-Niterink, A. J. 1981. Monograph of the genus Pythium. Studies in Mycology, Vol. 21. Centraalbureau voor Schimmelcultures, Baarn, Netherlands.

36. Waterhouse, G. E. 1967. Key to Pythium Pringsheim. Mycol. Pap. 109. Commonw. Mycol. Inst./Assoc. Appl. Biol., Kew, Surrey, Eng. 